\title{
Belemnocamax boweri Crick, an unusual belemnite from the Cenomanian of northwest Germany and eastern England
}

\author{
WALTER KEGEL CHRISTENSEN
}

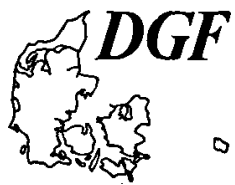

\begin{abstract}
Christensen, W. K.: Belemnocamax boweri Crick, an unusual belemnite from the Cenomanian of northwest Germany and eastern England. Bull. geol. Soc. Denmark, Vol. 40, pp. 157-166, Copenhagen, June 3th, 1993. https://doi .org/10.37570/bgsd-1993-40-06

A small population of Belemnocamax boweri Crick, 1910 from the Lower Middle Cenomanian primus bed in the limestone pit at Wunstorf west of Hannover (NW Germany) is studied by biometrical methods in order to analyse the variation of critical characters. The monotypic Belemnocamax differs from all other Upper Cretaceous belemnitellids by the small size of the guard, which is conical in ventral and lateral views, and by having a long, deep, and broad ventral groove. $B$. boweri is very rare and has only been recorded from eastern England and northwest Germany, where it occurs in the Lower Middle Cenomanian. The ancestry of this genus is unknown.
\end{abstract}

W. K. Christensen, Geological Museum, University of Copenhagen, Øster Voldgade 5-7, DK-1350 Copenhagen, Denmark: February 17th, 1992.

\section{Introduction}

Belemnocamax boweri was established by Crick (1910) on the basis of only two specimens from the Cenomanian Totternhoe Stone of Lincolnshire, England. This monotypic genus is so anomalous-looking that it was suggested by earlier authors, among others Stolley (1919) and Jeletzky (1946), that the two specimens were pathological forms of some Cenomanian belemnite species. This suggestion, however, was invalidated by records of this species from Lincolnshire and Norfolk by Wright \& Wright (1961). Later this taxon was reported from the Lower Saxony Basin in NW Germany by Zawischa (1980), Ernst, Schmid \& Seibertz (1986), and Dahmer \& Ernst (1986). Christensen, Diedrich \& Kaplan (1992) described Cenomanian belemnites, including two specimens of $B$. boweri, from the Teutoburger Wald at the northern margin of Münster Basin.

$B$. boweri is enigmatic, because it only occurs in the Lower Middle Cenomanian, has a very restricted geographic distribution (eastern England and northwest Germany) (Fig. 1), is rare, and its ancestry is unknown.

According to Crick (1910, p. 364) Belemnocamax is distinguished by its small conical guard, which has a broad ventral groove, fine longitudi- nal striae near the apex, and broad dorso-lateral depressions. The purpose of the present study is to describe in detail $B$. boweri, utilizing biometric analysis, on the basis of material collected recently in the limestone pit at Wunstorf west of Hannover, NW Germany. In addition material from England, housed in the Natural History Museum, London (prefix BMNH) and the Ge-

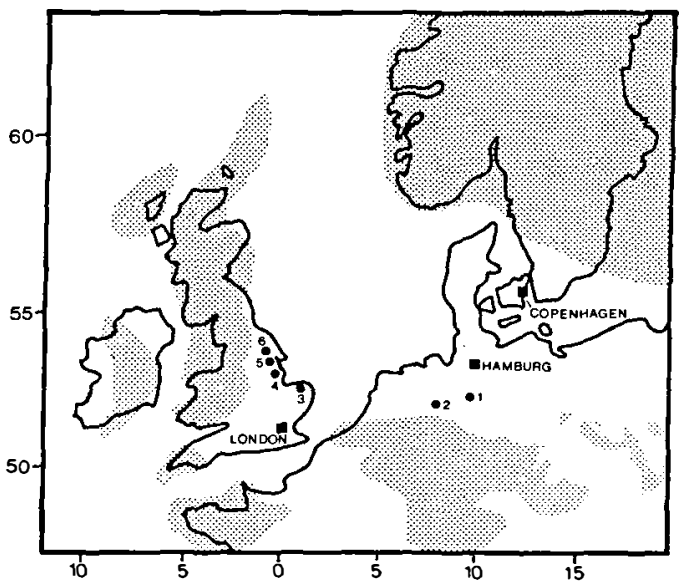

Fig. 1. Map showing Late Cenomanian shorelines. Stipple indicates land areas. Dots show localities where Belemnocamax boweri has been collected. 1 is Wunstorf, 2 is Dörenthe, 3 is Hunstanton, 4 is Louth, 5 is South Ferriby, and 6 is Market Weighton. The map is slightly modified from Tyson \& Funnell (1987). 
ological Museum, Copenhagen (prefix GM), has been studied. Casts of the figured German specimens are housed in the type collection of the Geological Museum, Copenhagen (prefix MGUH).

\section{Methods}

The following characters were measured: the length of the guard (L), the depth of the pseudoalvolus (D), the dorso-ventral diameter at the anterior end (DVDAE), the lateral diameter at the anterior end (LDAE), and the length of the ventral groove (LVG). The measurements were made with a vernier caliper to an accuracy of 0.1 mm.

In about half of the near-complete specimens the outermost apical end of the guard is missing. In these specimens the total length of the guard is estimated by adding $0.2-2.7 \mathrm{~mm}$ (optical estimate) to the preserved part of the guard (see below).

The variation of $B$. boweri is analyzed using univariate and bivariate statistical methods and is summarized by descriptive statistics and scatter diagrams. The statististical methods and tests used in the present paper were discussed in detail by Christensen (1975, pp. 31-33).

\section{Systematic palaeontology}

Order Belemnitida Zittel, 1895.

Suborder Belemnopseina Jeletzky, 1965.

Family Belemnitellidae Pavlow, 1914.

Genus Belemnocamax Crick, 1910.

Type species. By monotypy, Belemnocamax boweri Crick (1910).

Diagnosis. The guard is very small, conical in ventral and lateral views, and the apex is acute. The alveolus is not preserved due to incomplete calcification of the anterior end. Therefore, the anterior end has a pseudoalveolus, which exhibits the concentric growth layers of the guard, and the walls of the pseudoalveolus may carry conellae. The depth of the pseudoalveolus varies from about one seventh to one fourth of the length of the guard. The guard has a long, broad, and deep ventral groove that extends from the anterior end; it is generally one third to one fourth of the length of the guard. The dorso-lateral longitudinal depressions are well developed and delimits the dorsal field. The depressions start at the anterior end and can be followed almost to the apex. Single lateral furrows are present. The guard has longitudinal striae; it is otherwise smooth.

Occurrence. As for B. boweri (see below).

Discussion. The monotypic genus Belemnocamax is assigned to the family Belemnitellidae, because it has a pseudoalveolus showing the concentric growth layers of the guard, dorso-lateral longitudinal depressions, single lateral furrows, and longitudinal striae. It differs from all other belemnitellid genera by the size and shape of the guard and by having a long, broad, and deep ventral groove.

The genus name Belemnocamax should not be confused with the genus name Belemnellocamax Naidin, a Late Cretaceous belemnitellid genus. This genus includes species with large guards (up to $130 \mathrm{~mm}$ ), which are lanceolate or subcylindrical in ventral view and considerable flattened ventrally. Belemnellocamax is recorded from the Lower Santonian (possibly the uppermost Coniacian) to the lower Upper Campanian (Christensen 1986).

Belemnocamax boweri Crick, 1910

Figs 2-3

1910 Belemnocamax boweri Crick, p. 360, pl. 28 , figs 1-2.

1919 Belemnocamax boweri Crick; Stolley, p. 50.

1922 Belemnocamax boweri Crick; Naef, p. 256.

1946 Belemnocamax boweri Crick; Jeletzky, p. 96.

1951 Belemnocamax boweri Crick; Wright \& Wright, p. 10.

1961 Belemnocamax boweri Crick; Peake \& Hancock, p. 302.

1980 Belemnocamax boweri Crick; Zawischa, p. 25, text-fig. 74.

1981 Belemnocamax boweri Crick; Wood, p. 97.

1983 Belemnocamax boweri Crick; Ernst, Schmid \& Seibertz, p. 545. 


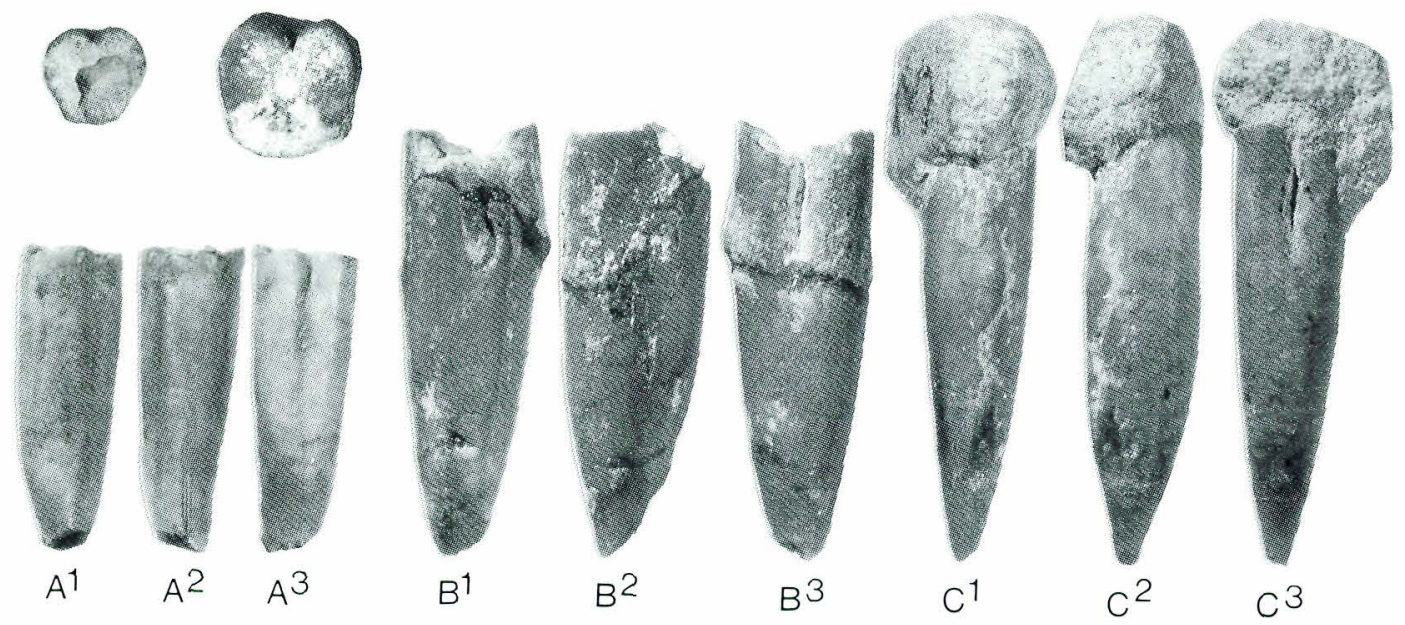

Fig. 2. Belemnocamax boweri Crick from England. All figures are $\times 3.1$ is dorsal view; 2 is lateral view; 3 is ventral view; and 4 is view of the anterior end.

A: BMNH C12447, Louth, Lincolnshire, holotype.

B: BMNH C46451, Totternhoe Stone, Hunstanton

C: BMNH C46305, Totternhoe Stone, Hunstanton.

Photography: Natural History Museum, London.

1986 Actinocamax boveri (Crick); Dahmer \& Ernst, p. 357.

1987c Belemnocamax boweri Crick; Doyle, p. 191, pl. 41, figs 9-12.

1990a Belemnocamax boweri Crick; Christensen, p. 86.

1990 Belemnocamax boweri Crick; Meyer, p. 31.

1991 Belemnocamax boweri Crick; Whitham, p. 234.

Type. The holotype, by original designation, is the original of Crick (1910, pl. 38: fig. 1), reproduced here as Fig. 2A, from the Lower Middle Cenomanian Totternhoe Stone, Welton Vale, 2 miles west of Louth, Lincolnshire. It is housed in the Natural History Museum, London, BMNH C12447. The paratype figured by Crick (1910, pl. 38, fig. 2) is apparently lost. Dimensions of the holotype are shown below.

Material. 18 specimens from the primus bed of the limestone pit at Wunstorf west of Hannover, Lower Saxony Basin, A. rhotomagense Zone, $T$. costatus Subzone (Fig. 5); 3 specimens from the same horizon of the abandoned quarry ' $O$. Breckweg' in Dörenthe southwest of Osnabrück at the northern margin of the Münster Basin; BMNH C12447 (holotype), Totternhoe Stone, Lincolnshire, Lower Middle Cenomanian; BMNH C46305, C46451, and GM 1992.247, Totternhoe Stone, Hunstanton, Norfolk; BMNH C59286-7, Hunstanton, 'Schloenbachia varians Zone'; and BMNH C59288-9, Rifle Butts pit, Market Weighton, Yorkshire, 'Schloenbachia varians Zone'.

BMNH C59290 from the Cenomanian ' $H$. subglobosus Zone' of the Isle of Wight is labelled $B$. boweri (see also Wright \& Wright 1951). This specimen is not a belemnite, but the small, fixed finger of an indeterminable brachyuran crustacean.

The German material of $B$. boweri was collected by a group of private collectors, including F. Wittler, U. Frerichs, A. Gassner, Inga Krause, D. Zawischa, K. Höll, J. Schormann, and M. Link. BMNH C59286-89 originate from the C. W. \& E. V. Wright Collection, and GM 1992.247 was collected by Dr. A. S. Gale, London. 

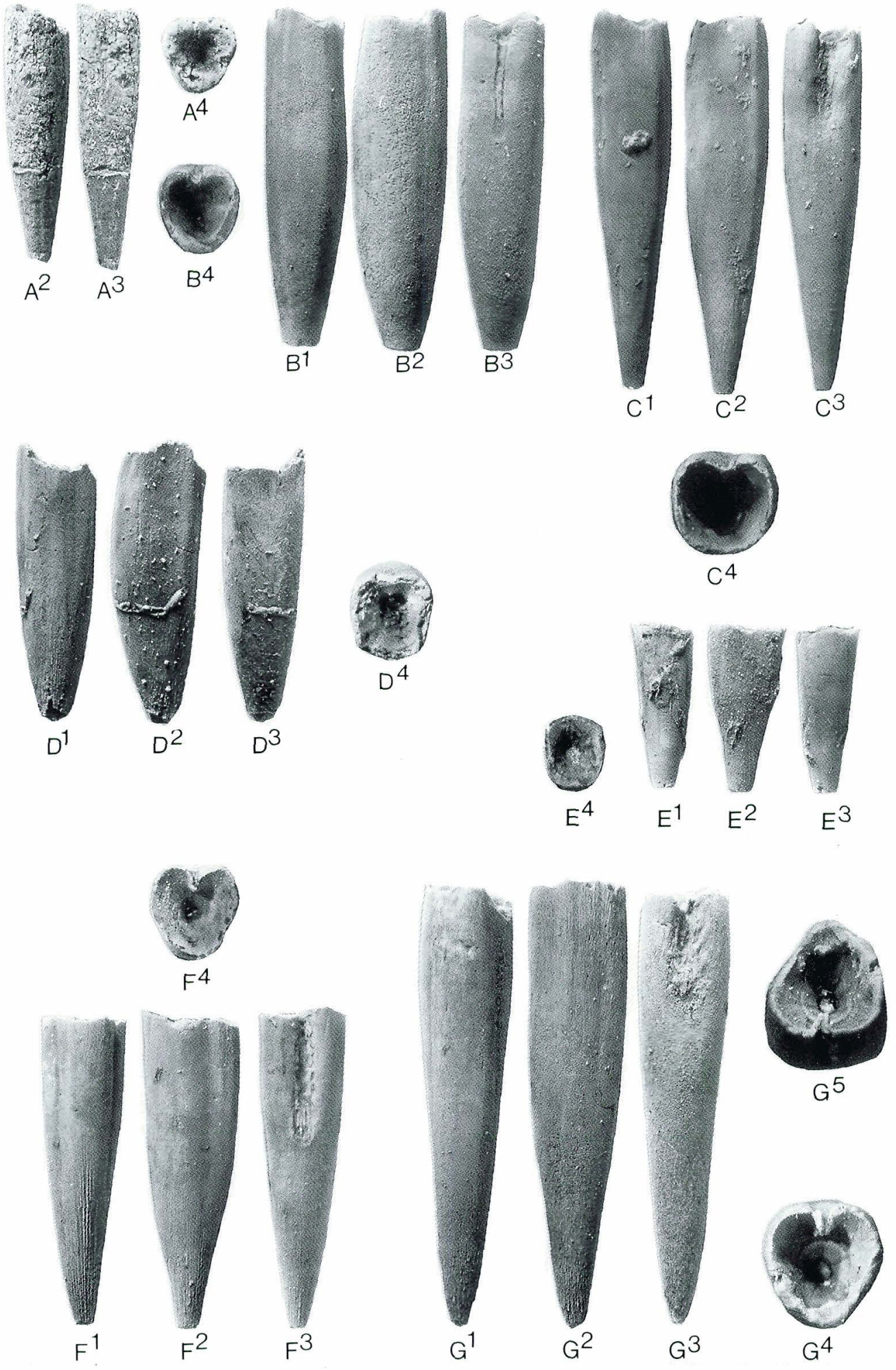
Dimensions.

\begin{tabular}{|c|c|c|c|c|c|c|}
\hline & $\mathbf{L}$ & Preserved L & $\mathrm{D}$ & DVDAE & LDAE & LVG \\
\hline \multicolumn{7}{|l|}{ English material } \\
\hline BMNH C12447 & $12^{*}$ & 10.3 & 2.0 & 3.3 & 3.5 & 4.5 \\
\hline BMNH C46305 & $19^{*}$ & 14.3 & - & - & - & 4.8 \\
\hline BMNH C46451 & $15.5^{*}$ & 14.6 & 2.2 & 4.9 & 4.5 & 5.6 \\
\hline BMNH C59286 & - & - & - & - & - & - \\
\hline BMNH C59287 & - & - & - & - & - & - \\
\hline BMNH C59288 & - & 9.1 & - & - & - & - \\
\hline BMNH C59289 & - & 7.3 & - & - & - & - \\
\hline \multicolumn{7}{|l|}{ German material } \\
\hline W1 & $15^{*}$ & 12.9 & 3.2 & 3.5 & 3.1 & 3.0 \\
\hline W2 & $20^{*}$ & 19.2 & 5.1 & 3.1 & 3.0 & 3.6 \\
\hline W3 & $23^{*}$ & 22.8 & 4.1 & 4.8 & 4.5 & 2.6 \\
\hline W4 & 13.6 & - & 2.6 & 3.5 & 3.2 & 3.2 \\
\hline W5 & $6.5^{*}$ & 6.2 & 1.5 & 2.7 & 2.2 & np \\
\hline W6 & - & 11.4 & - & - & - & - \\
\hline W7 & - & 11.3 & 4.1 & 4.3 & 4.1 & 6.3 \\
\hline W11 & 11.4 & - & 1.7 & 2.9 & 3.0 & 1.1 \\
\hline W12 & $13^{*}$ & 12.2 & 2.8 & 3.5 & 3.2 & 3.7 \\
\hline W13 & $11.5^{*}$ & 10.6 & $2.2^{*}$ & 3.3 & 3.0 & $n p$ \\
\hline W14 & $13^{*}$ & 11.3 & 3.1 & 3.2 & 3.3 & 2.7 \\
\hline W15 & 19.5 & - & 4.5 & 4.6 & 4.6 & 5.2 \\
\hline W16 & - & 5.1 & 1.5 & 2.8 & 2.5 & $n p$ \\
\hline W17 & 15.0 & - & - & 3.1 & 3.2 & - \\
\hline W18 & 18.5 & - & - & - & - & - \\
\hline W19 & 16.0 & - & - & 3.2 & 3.3 & 3.7 \\
\hline D2 & $14.5^{*}$ & 13.4 & 2.3 & 3.4 & 3.1 & 3.6 \\
\hline
\end{tabular}

*: estimated; np: ventral groove not present.

Description of the sample from Wunstorf. It consists of a growth series containing juvenile, adolescent, and adult specimens.

The guard is very small (up to $23 \mathrm{~mm}$ long, mean value $c .15 \mathrm{~mm}$ ) and conical in ventral and lateral view. The shape of the guard is variable due to allometric growth (see below): adult specimens are more slender than juvenile specimens. The apex is placed centrally or is slightly displaced towards the dorsal side. The apical end is acute. The guard is flattened ventrally.

The alveolus is not preserved due to incom- plete calcification of the anterior end. Therefore, the anterior end is developed as a pseudoalveolus, the depth of which varies from about one quarter to one seventh of the length of the guard (mean value of $L / D$ is 4.8 ; see below). The pseudoalveolus exhibits the concentric growth layers of the guard, and the walls may carry conellae (Fig. 3G). Radiating ribs are not present. The cross section of the pseudoalveolus is generally subtriangular or heart shaped, and may be subquadratic or almost circular with a ventral notch.

The guard has anteriorly a long, deep, and

Fig. 3. Belemnocamax boweri Crick from NW Germany. A is from Dörenthe, Münster Basin, and B-G are from Wunstorf, Lower Saxony; Lower Middle Cenomanian, A. rhotomagense Zone, $T$. costatus Subzone. Specimens are coated with ammonium chloride. All figures are $\times 3$ unless otherwise stated. 1 is dorsal view; 2 is lateral view; 3 is ventral view; and $4-5$ are view of the anterior end. A: D2, a medium-sized specimen. F. Wittler Colln = MGUH 22063.

B: W1, a medium-sized specimen, $\times 4$. The cross-section of the anterior end is heart-shaped. U. Frerichs Colln $=$ MGUH 22064.

C: W2, a large specimen with a deep pseudoalveolus and striation apically and on the dorsal anterior end; C4 is $\times 4$. U. Frerichs Colln $=$ MGUH 22065 .

D: W13, a medium-sized specimen showing striation on the posterior half of the guard. The dorsal field is prominent and a ventral groove is not present; $\times 4$. Collection of Niedersächsiches Landesamt für Bodenforschung, Hannover $=$ MGUH 22066.

E: W5, the smallest specimen, which does not have a ventral groove; $\times 4$. I. Krause Colln = MGUH 22067.

F: W12, a medium-sized specimen showing striation apically and on the dorsal field. The cross-section of the anterior end is heart-shaped and the dorsal field is very prominent; $\times 4$. D. Zawischa Colln $=$ MGUH 22068.

G: W3, the largest specimen showing striation apically and anteriorly. The cross-section of the anterior end is heart-shaped, and the pseudoalveolus carries conellae (G5); G4-5 are $\times 4$. A. Gassner Colln = MGUH 22069. 
Table I. Biometric analysis of Belemnocamax boweri from Wunstorf. $\mathrm{L}=$ length of the guard; $\mathrm{D}=$ depth of the pseudoalveolus; DVDAE = dorso-ventral diameter at the anterior end; LDAE = lateral diameter at the same place; $L V G=$ length of ventral groove; $\mathrm{N}=$ number of specimens; $\overline{\mathrm{X}}=$ mean value; $\mathrm{SD}=$ standard deviation; $\mathrm{CV}=$ coefficient of variation; $\mathrm{OR}=$ observed range; $\mathrm{r}=$ correlation coefficient; $\mathrm{SD}_{\mathrm{a}}=$ standard deviation of the intercept; $\mathrm{SD}_{\mathrm{b}}=$ standard deviation of the slope; $\mathrm{SD}_{\mathrm{yx}}=$ standard deviation of the regression line. All measurements in $\mathrm{mm}$. Three specimens do not have a ventral groove. LVG* is calculated on the basis of 13 specimens, including the specimens without a ventral groove, and LVG is calculated on the basis of 10 specimens.

Univariate analysis:

\begin{tabular}{lllllr}
\hline Character & $\mathrm{N}$ & $\overline{\mathrm{X}}$ & $\mathrm{SD}$ & $\mathrm{CV}$ & OR \\
\hline L & 13 & 15.1 & 4.4 & 29.0 & $6.5-23.0$ \\
D & 12 & 3.0 & 1.2 & 43.9 & $1.5-5.1$ \\
DVDAE & 14 & 3.5 & 0.7 & 18.9 & $2.7-4.8$ \\
LDAE & 14 & 3.3 & 0.7 & 20.5 & $2.2-4.6$ \\
LVG & 13 & 2.7 & 2.0 & 73.1 & $0-6.3$ \\
LVG & 10 & 3.5 & 1.4 & 23.0 & $1.1-6.3$ \\
L/D & 10 & 4.8 & 0.9 & 17.7 & $3.9-6.7$ \\
L/DVDAE & 12 & 4.3 & 1.0 & 23.0 & $2.4-6.5$ \\
\hline
\end{tabular}

Bivariate analysis:

(1) $\mathrm{D}=-0.1371+0.2196 \mathrm{~L} ; \mathrm{N}=10 ; \mathrm{r}=0.9069 ; \mathrm{SD}_{\mathrm{a}}=0.5544 ; \mathrm{SD}_{\mathrm{b}}=0.0361 ; \mathrm{SD}_{\mathrm{yx}}=0.5295$.

(2) DVDAE $=1.8704+0.1068 \mathrm{~L} ; \mathrm{N}=12 ; \mathrm{r}=0.7492 ; \mathrm{SD}_{\mathrm{a}}=0.5023 ; \mathrm{SD}_{\mathrm{b}}=0.0298 ; \mathrm{SD}_{\mathrm{yx}}=0.4390$.

broad ventral groove, the length of which generally is one third to one quarter of the length of the guard. In some specimens the ventral wall of the pseudoalveolus, housing the groove, is folded into the pseudoalveolus, producing a prominent ridge in the pseudoalveolus (Figs 3B, 3F, 3G). The cross-section of the anterior end of these specimens is therefore heart-shaped or subcircular with a ventral notch. The groove may be shorter or may not be present (Figs 3D-E). Dorso-lateral depressions are well developed and delimit the prominent dorsal field. The dorsolateral depressions extend at the anterior end and continue almost to the apex. Single lateral furrows are present. The guard has longitudinal striae; these may be present anteriorly, apically, and on the dorsal field. Otherwise the guard is smooth.

Univariate analysis. The estimates of the statistical parameters are shown in Table 1.

Bivariate analysis. The scatter plots of the length of the guard versus the depth of the pseudoalveolus, and the length of the guard versus the dorsoventral diameter are shown in Fig. 4, as are the regression lines. The equations of the regression lines are shown in Table 1.

The correlation coefficient of the first analysis is very highly significant $(\mathrm{P}>0.01$ with 8 degrees of freedom). The correlation of the second analysis is highly significant $(0.01>\mathrm{P}>0.001$ with 10 degrees of freedom). t-tests on the intercept on the $y$-axis were performed to see if the intercepts differed significantly from zero. In the first analysis the t-test gives a value of 0.2473 with 8 degrees of freedom, which is not significant $(0.90>\mathrm{P}>$ 0.80 ), implying an isometric relationshp of the two variates. If the correlation coefficient is perfect $(r=1.0000)$, the ratio of the length of the guard and the depth of the pseudoalveolus is 4.8 in both juvenile and adult specimens. Owing to individual variation, this ratio varies from 3.9 to 6.7. In the second analysis the t-test gives a value of 3.7234 with 10 degrees of freedom, which is highly significant $(0.005>P>0.001)$, implying an allometric relationship of the two variates. If the correlation is perfect $(\mathrm{r}=1.0000)$, the ratio of the two variates would vary in the following way:

\begin{tabular}{rc}
\hline L & LDVDAE \\
\hline 6 & 2.4 \\
10 & 3.4 \\
14 & 4.2 \\
18 & 4.7 \\
22 & 5.2 \\
\hline
\end{tabular}

Owing to individual variation, the ratio varies from 2.4 to 6.5 (an adult specimen).

Discussion. One specimen of $B$. boweri from Dörenthe, NW Germany, and two specimens from 

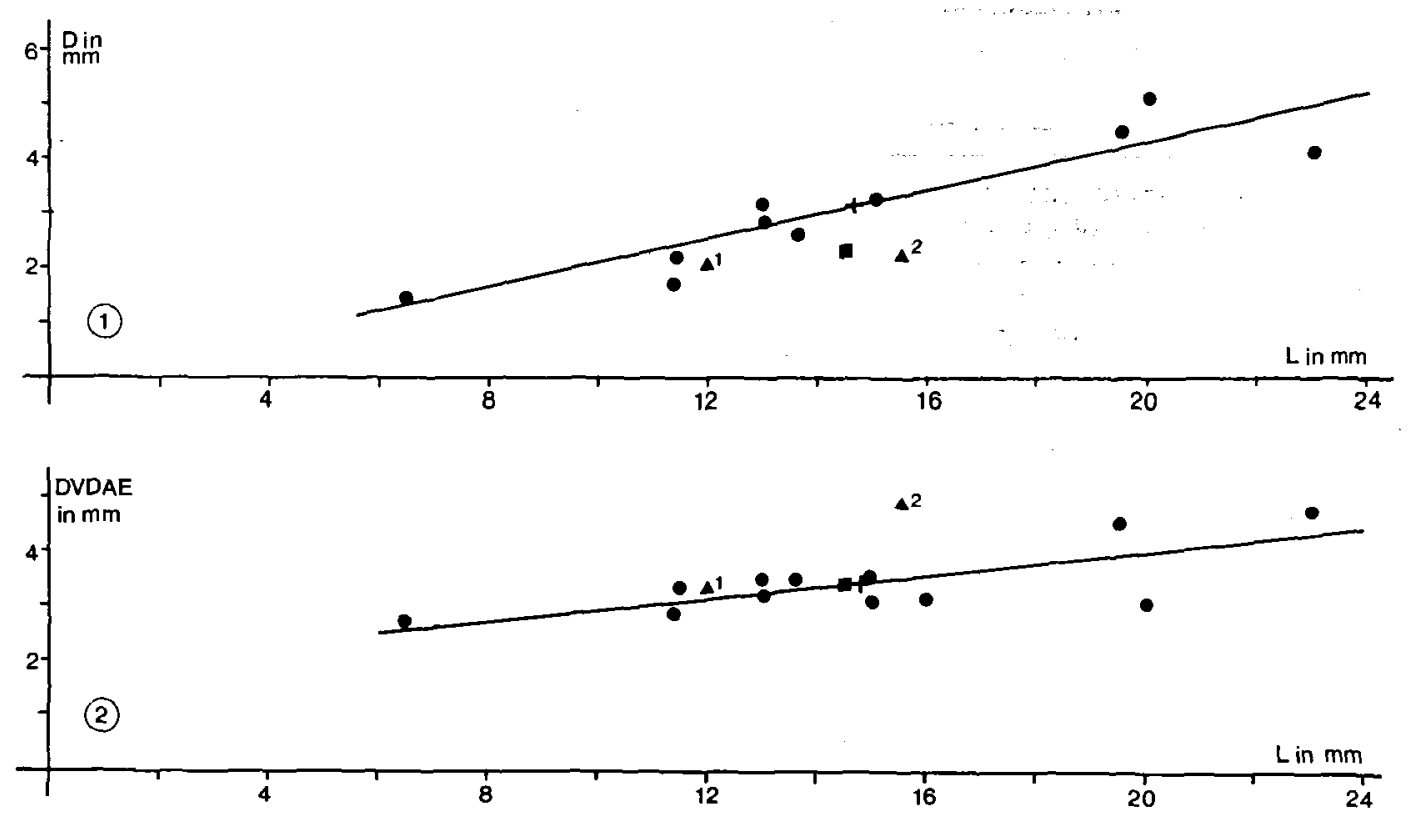

Fig. 4. Scatter plots and regression lines for Belemnocamax boweri from Wunstorf in the Lower Saxony Basin (dots). 1: the length of the guard (L) versus the depth of the pseudoalveolus (D); 2: the length of the guard (L) versus the dorso-ventral diameter at the anterior end (DVDAE); + = mean value. One specimen from Dörenthe in the Münster Basin (square) and two specimens from eastern England (triangles) are also plotted. 1 is BMNH C12447 (holotype) from Louth in Lincolnshire, and 2 is BMNH C4645I from Hunstanton in Norfolk.

Lincolnshire and Norfolk, respectively, are plotted in Fig. 4. With respect to the length of the guard versus the depth of the pseudoalveolus, the three specimens plot below the regression line for the sample from Wunstorf, showing that these specimens have a more shallow pseudolaveolus than the specimens from Wunstorf. Particularly BMNH C46451 has a rather shallow pseudoalveolus. With respect to the length of the guard versus the dorso-lateral diameter at the anterior end, the holotype plots very close to the regression line and the specimen from Dörenthe is situated on the regression line. BMNH C46451 is stout and plots above the regression line. These differences probably reflect morphological variation, and are not considered to be of taxonomic importance.

The small population from Wunstorf, consisting of 18 specimens, includes juvenile, adolescent, and adult specimens, suggesting that the species lived and reproduced in that area. Less than 10 specimens from eastern England have been studied, but the material from Hunstanton includes both juvenile and adult specimens, suggesting that the taxon lived and reproduced in that area too.
Distribution. B. boweri occurs in Norfolk, Lincolnshire, and Yorkshire in eastern England, in addition to Wunstorf in the Lower Saxony Basin and Dörenthe in the Münster Basin.

In northwest Germany it occurs together with Actinocamax primus Arkhangelsky in the primus bed of Early Middle Cenomanian age (see Christensen 1990a, Christensen et al. 1992) (Fig. 5). The carefull records by Whitham (1991) show that $B$. boweri occurs in the upper part of the Totternhoe Stone of Yorkshire, while $A$. primus occurs in the lower part of this marker bed. He also recorded $B$. boweri from South Ferriby at a level approximating the so-called Gryphaea band of Yorkshire. This band is situated about $4 \mathrm{~m}$ above the Totternhoe Stone. B. boweri is also recorded from the Totternhoe Stone of Lincolnshire and Norfolk. The Totternhoe Stone at Burwell, Cambridgeshire is Lower Middle Cenomanian (Wright, Kennedy \& Hancock 1984), and has yielded $A$. primus (see Christensen 1990a). The Totternhoe Stone and Gryphaea band in Norfolk, Lincolnshire, and Yorkshire are supposed to be of the same age (Peake \& Hancock 1961, Wood 1981). 


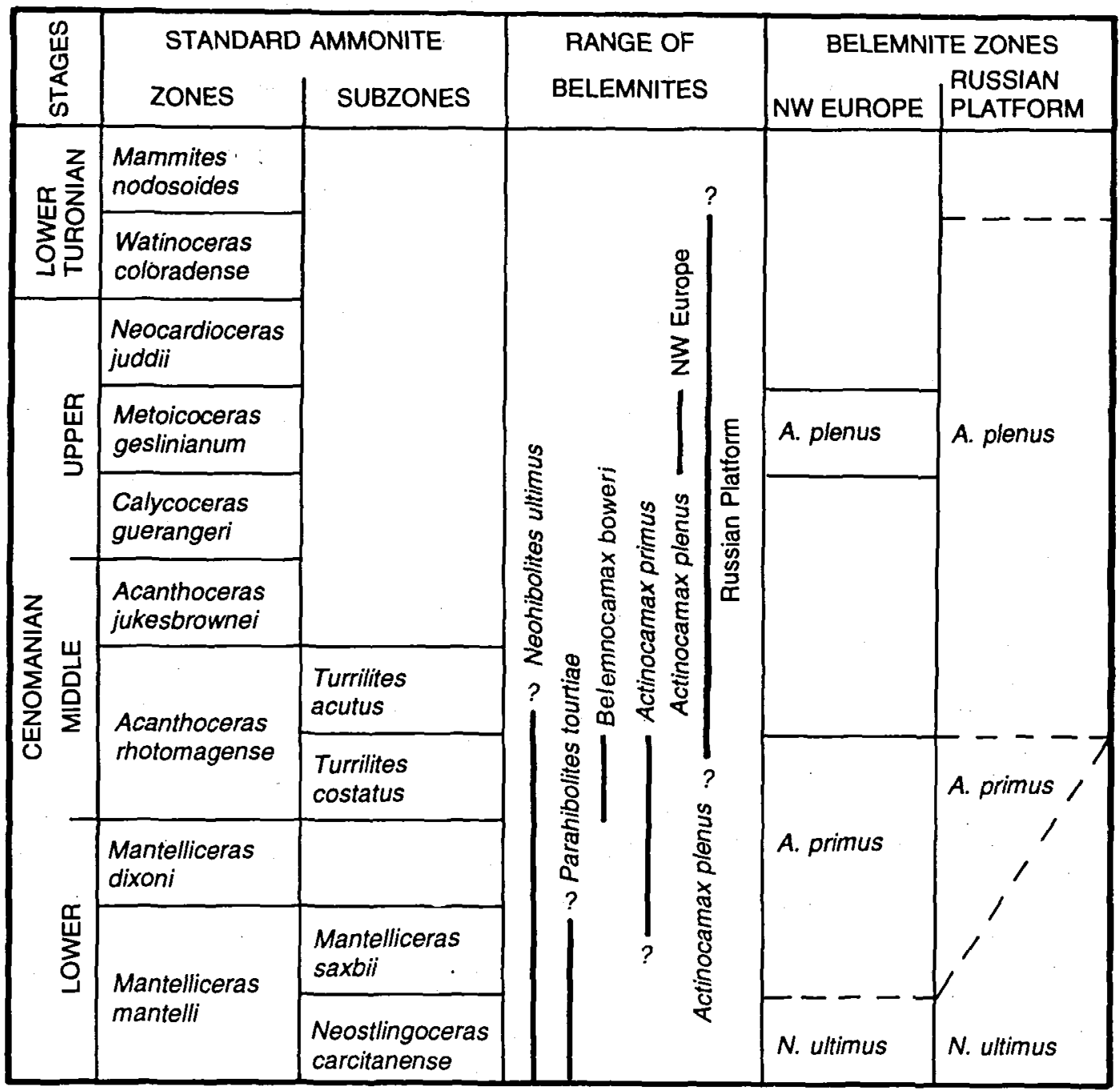

Fig. S. Stratigraphical diagram of the Cenomanian and Lower Turonian showing standard ammonite zones and subzones, belemnite zones, and range of belemnites.

The ancestry of the genus

\section{Belemnocamax}

Actinocamax primus Arkhangelsky is the earliest member of the Belemnitellidae and appears some distance above the base of the Lower Cenomanian (Christensen 1990a) (Fig. 5). It is followed upwards by the closely allied $A$. plenus (Blainville), which in NW Europe occurs in the Middle Upper Cenomanian; the two species form an evolutionary lineage (Christensen 1990a). According to Jeletzky (1946) all Upper Cretaceous belemnitellid genera are derived from the Cenomanian Actinocamax rootstock. As noted above, Je- letzky (1946) considered the holotype and paratype of $B$. boweri to be pathological forms of some Cenomanian belemnite species. Jeletzky (1946) also suggested that the belemnitellids are derived from the Tethyan belemnopseids Neohibolites ewaldi (Strombeck) or N. clava Stolley, which occur in the Aptian. This assumption was based on the similarity of the shape of the guard and the structure of the anterior end of the Aptian species of Neohibolites Stolley and the Actinocamax primus-plenus lineage. Doyle (1987a, 1988) suggested that the belemnitellids may have evolved from a northern endemic stock of the 
Tethyan belemnopseid Hibolithes Montfort in the later Early Cretaceous.

$B$. boweri appears slightly later than $A$. pri$m u s$, but a derivation from this species, as well as Lower Cretaceous species of Hibolithes and NeOhibolites, is unlikely on account of its size and shape of the guard and its broad and deep ventral groove. Jeletzky (unpublished manuscript, 1972) suggested that Belemnocamax probably represents an early independent offshoot of a still unknown pre-Cenomanian form between Neohibolites and Actinocamax, and that this aberrant genus died out without issue.

\section{The Cenomanian belemnite faunas of NW Europe}

The Upper Cretaceous North European palaeobiogeographic Province is characterized by the belemnitellids and extends from Ireland in the west to the Ural Mountains in the east (Christensen $1975,1976,1990 \mathrm{~b})$. The last representatives of the Tethyan belemnopseids became extinct in the Middle Cenomanian. A widespread AptianAlbian migration away from Tethys into both the northern and southern hemisphere of the belemnopseids Neohibolites and Parahibolites has been suggested by Doyle (1987b, 1988; see also Mutterlose et al. 1983). In the Cenomanian these genera have been recorded as far north as NW Germany and eastern and southern England.

Five species belonging to four genera occur in the Cenomanian of NW Europe: the belemnopseids Parahibolites tourtiae (Weigner) and Neohibolites ultimus (d'Orbigny), in addition to the belemnitellids Actinocamax primus Arkhangelsky, A, plenus (Blainville), and Belemnocamax boweri. The stratigraphic range of these taxa is shown in Fig. 5, which is based on Combémorel Christensen Naidin \& Spaeth (1981), Christensen (1990a 1990b), Christensen, Juignet, Breton \& Cottard (in press), and Christensen, Diedrich \& Kaplan (1992).

\section{Conclusions}

The small, anomalous-looking $B$. boweri is described on the basis of material collected recently in the limestone pit at Wunstorf west of Han- nover in addition to English material which includes the holotype. The variation of critical characters is analyzed by univariate and bivariate biometric methods. It is shown that the relationship of the length of guard versus the depth of the pseudoalveolus is isometric, and that the relationship of the length of the guard versus the dorso-ventral diameter at the anterior end is allometric. Therefore, the ratio of the length of the guard and the depth of the pseudoalveolus does not change during growth, whereas the ratio of the length of the guard and the dorso-ventral diameter at the anterior end increases during growth. Adult specimens are thus more slender than juvenile specimens. The monotypic genus Belemnocamax is distinguished by the very small size of the guard, which is conical in ventral and lateral views and by having a deep, broad ventral groove. It is very rare (less than 30 specimens are recorded) and is only recorded from eastern England and northwest Germany, where it occurs in the Lower Middle Cenomanian.

Acknowledgments. Thanks are directed to Mrs. Inga Krause, Mr. F. Wittler, Mr. A. Gassner, Dr. D. Zawischa, Mr. K. Höll, Mr. J. Schormann, Mr. M. Link, Mr. U. Frerichs, Prof. F. Schmid, who placed German material of $B$. boweri at my disposal, Dr. A. S. Gale, who gave me a specimen of $B$. boweri from Norfolk, and Dr. P. D. Taylor, who allowed me to study specimens housed in the Natural History Museum, London. I also thank Mr. Sten L. Jakobsen for technical support. The late Dr. J. A. Jeletzky kindly provided me with a copy of his unpublished manuscript intended for Treatise on Invertebrate Paleontology in 1972. This study is supported by the Carlsberg Foundation.

\section{Dansk sammendrag}

En lille population af den særprægede belemnit Belemnocamax boweri Crick, 1910 fra den Nedre Mellem Cenomane primus bænk i kalkbruddet ved Wunstorf vest for Hannover (Nordvesttyskland) er undersøgt biometrisk for at analysere variationen af vigtige karakterer. Den monotypiske slægt Belemnocamax afviger fra alle andre slægter af familien Belemnitellidae Pavlow fra $\emptyset_{v r e}$ Kridt ved sit meget lille rostrum, som er konisk set fra ventral og lateral siden, samt ved at have en dyb og bred ventral fure fortil. $B$. boweri er meget sjelden og kendes kun fra det østlige England og Nordvesttyskland, hvor den findes i lag fra Nedre Mellem Cenoman. Dens oprindelse er ukendt.

\section{References}

Christensen, W. K. 1975: Upper Cretaceous belemnites from the Kristianstad area in Scania, Sweden. Fossils and Strata $7,69 \mathrm{pp}$.

Christensen, W. K. 1976: Palaeobiogeography of Late Cretace- 
ous belemnites of Europe. Paläontologische Zeitschrift 50, 113-129.

Christensen, W. K. 1986: Upper Cretaceous belemnites of the Vomb Trough in Scania, Sweden. Sveriges geologiske Undersökning Ca57, 57 pp.

Christensen, W. K. 1990a: Actinocamax primus Arkhangelsky (Belemnitellidae; Upper Cretaceous), Biometry, comparison and biostratigraphy. Paläontologische Zeitschrift 64, 75-90.

Christensen, W. K. 1990b: Upper Cretaceous belemnite stratigraphy of Europe. Cretaceous Research 11, 371-386.

Christensen, W. K., Diedrich, C. \& Kaplan, U. (1992): Cenomanian belemnites from the Teutoburger Wald, NW Germany. Paläontologische Zeitschrift 66, 265-275.

Christensen, W. K., Juignet, P., Breton, G. \& Cottard, N. (in press): Bélemnites du Cretacé supérieur de Normandie (France). Bulletin trimestriel de la Société Géologique de Normandie et des Amis du Muséum du Havre.

Combémorel, R., Christensen, W. K., Naidin, D.P. \& Spaeth, C. 1981: Les Bélemnites. Cretaceous Research 2, 283-286.

Crick, G. C. 1910: On Belemnocamax boweri, n.g. et sp. A new cephalopod from the Lower Chalk of Lincolnshire. Proceceedings of the Geologists' Association 21, 360-365.

Dahmer, D.-D. \& Ernst, G. 1986: Upper Cretaceous event stratigraphy in Europe. In Walliser, O. (Ed.): Global BioEvents, Lecture Notes in Earth Sciences 8, 353-362.

Doyle, P. 1987a: The Cretaceous Dimitobelidae (Belemnitida) of the Antarctic Peninsula region. Palaeontology 30, 147177.

Doyle, P. 1987b: Early Cretaceous belemnites from southern Mozambique. Palaeontology 30, 311-317.

Doyle, P. 1987c: Belemnites. In Owen, E. (Ed.): Fossils of the Chalk. Field Guides to Fossils 2, 183-191. Palaeontological Association, London.

Doyle, P. 1988: The belemnite family Dimitobelidae in the Cretaceous of Gondwana. In Wiedmann, J. \& Kullmann, J. (Eds.): Cephalopods - present and past, 539-552. Schweizerbart'sche Verlagsbuchhandlung, Stuttgart.

Ernst, G., Schmid, F. \& Seibertz, E. 1983: Event-Stratigraphie im Cenoman und Turon von NW-Deutschland. Zitteliana 10, 531-554.

Jeletzky, J. A. 1946: Zur Kenntnis der Oberkretazischen Be- lemniten. Geologiska Föreningens i Stockholm Förhandlingar 68, 87-105.

Meyer, T. 1990: Biostratigraphische und sedimentologische Untersuchungen in der Plänerfazies des Cenoman von Nordwestdeutschland. Mitteilungen aus dem Geologischen Institut der Universität Hannover 30, iv $+114 \mathrm{pp}$.

Mutterlose, J., Schmid, F. \& Spaeth, C. 1983: Zur Palaeobiogeographie von Belemniten der Unter-Kreide in NW-Europa. Zitteliana 10, 293-307.

Naef, A. 1922: Die fossilen Tintenfische, 322 pp. Verlag von Gustav Fischer, Jena.

Pavlow, A. P. 1914: Jurassic and Lower Cretaceous Cephalopoda of northern Siberia. Imperatovskoi Akademii Nauk, St Petersburg, Zapiski Seriia 8, Fizino-mathematicheskii otdel 21, $68 \mathrm{pp}$. [In Russian].

Peake, N. B. \& Hancock, J. M. 1961: The Upper Cretaceous of Norfolk. Transactions of the Norfolk and Norwich Naturatists' Society 19, 269-339.

Stolley, E. 1919: Die Systematik der Belemniten. Jahresbericht des Niedersächsischen geologischen Vereins 11, 1-59.

Tyson, R. V. \& Funnell, B. M. 1987: European Cretaceous shorelines, stage by stage. Palaeogeography, Palaeoclimatology, Palaeoecology 59, 69-91.

Whitham, F. 1991: The stratigraphy of the Upper Cretaceous Ferriby, Welton and Burnham formations north of the Humber, north-east England. Proceedings of the Yorkshire Geological Society 48, 227-254.

Wood, C. J. 1981: Upper Cretaceous. In Kent, P. (Ed.): Eastern England from the Tees to the Wash, 92-105. Institute of Geological Sciences, London.

Wright, C. W., Kennedy, W. J. \& Hancock, J. M. 1984: Introduction. In Wright, C. W. \& Kennedy, W. J.: The Ammonoidea of the Lower Chalk, 1-37. Palaeontological Society Monographs. (Publication No. 567, part of Vol. 137 for 1983).

Wright, C. W. \& Wright, E. V. 1951: A survey of the fossil cephalopoda of the chalk of Great Britain. Monograph of the Pdlaeontological Society London, $40 \mathrm{pp}$.

Zawischa, D. 1980: Die Fauna des Cenoman von Wunstorf. Arbeitskreis Paläontologie Hannover 8, 1-34.

Zittel, K. A. von 1895: Grundzüge der Paläontologie (Paläozoologie), $971 \mathrm{pp}$. R. Oldenburg, Munich and Leipzig. 